\title{
Pre-empting Protectionism in Services: The WTO and Outsourcing
}

\author{
Aaditya Mattoo* \\ Sacha Wunsch**
}

\begin{abstract}
Cross-border trade in services is growing rapidly, with both developed and developing countries among the most dynamic exporters. Despite the substantial global benefits from such trade, the adjustment pressures created in importing countries could provoke a protectionist backlash - some signs of which are already visible in procurement and regulatory restrictions. The current negotiations under the Doha Development Agenda offer an opportunity to lock in current openness and preempt protectionism. This note describes how a bold initiative under the General Agreement on Trade in Services (GATS) can help secure openness.
\end{abstract}

World Bank Policy Research Working Paper 3237, March 2004

The Policy Research Working Paper Series disseminates the findings of work in progress to encourage the exchange of ideas about development issues. An objective of the series is to get the findings out quickly, even if the presentations are less than fully polished. The papers carry the names of the authors and should be cited accordingly. The findings, interpretations, and conclusions expressed in this paper are entirely those of the authors. They do not necessarily represent the view of the World Bank, its Executive Directors, or the countries they represent. Policy Research Working Papers are available online at http:/lecon.worldbank.org.

*World Bank, **Institute for International Economics. Discussions with Rudolf Adlung, Abdel-Hamid Mamdouh and Juan Marchetti were critical to developing the arguments presented here. The comments of Crawford Falconer, Bernard Hoekman, Alejandor Jara, Deepak Mishra, Julia Nielson, Anirudh Shingal, B.K. Zutshi and other participants in seminars in India and Paris are gratefully acknowledged. 


\section{SUMMARY}

Cross-border trade in services is growing rapidly, with both developed and developing countries among the most dynamic exporters. Despite the substantial global benefits from such trade, it is possible that the adjustment pressures created in importing countries could provoke a protectionist backlash - some signs of which are already visible in procurement and regulatory restrictions. The current negotiations under the Doha Development Agenda offer an opportunity to preempt protectionism. This is best accomplished not by perpetuating the WTO's decision on duty free electronic commerce, but by comprehensive commitments on cross-border trade in services under the GATS. Full commitments on market access and national treatment would preclude, respectively, all quantitative restrictions and all forms of discrimination against foreign providers.

However, previous experience of the GATS negotiations and initial offers of access by Members in the current round suggest that comprehensive coverage will not be easy to accomplish, for two reasons. First, in the current GATS framework, the market access commitments of each WTO Member apply only to the sectors it chooses to list. So if a service is not explicitly listed then a Member remains free to restrict on trade in that service. This "positive listing" approach places a heavy burden on the services classification scheme used by Members. The existing classification scheme does not cover all the services being traded today, such as the services offered by call centers. Revising the classification does not offer a durable solution because no classification scheme can keep up with changes in technology, business practices and skills, and anticipate the ever-widening range of new services that will be traded.

Second, WTO Members traditionally negotiate access in services through the "request-and-offer" approach which involves negotiating commitments trading partner by trading partner, sector-bysector. This is a painful task with high costs in terms of negotiating resources; does not necessarily produce efficient or equitable outcomes in a world of unequal bargaining power; is affected by the free-rider problem that arises in negotiations conducted under an MFN-based system; and offers no credible way of granting credit to the unilateral liberalizers. Not surprisingly, past services negotiations have produced a meager harvest of liberalizing commitments.

More innovative approaches are necessary, and should be possible, since the issue in cross-border trade is not to induce countries to eliminate protection but simply to lock in their currently open regimes. The paper suggests two possibilities. The less ambitious Option 1 is for WTO Members to make liberalizing commitments on the basis of a model schedule designed to cover the information technology and business process outsourcing (BPO) services that are at the heart of the current trade boom. An essential step is to map the IT and BPO services being traded today into the existing GATS classification scheme, a task this note undertakes.

In the forward looking Option 2, both the classification and negotiating problem may be addressed through an innovative proposal requiring that all (or a critical mass of) WTO Members commit not to impose any restrictions on cross-border trade in any except a mutually agreed (narrow) set of services. Such a proposal would combine two elements: a negative list approach for cross-border trade that finesses the whole classification issue by treating all services as covered except the explicitly excluded few; and a "formula" approach that avoids the difficulty of the request-and-offer approach by requiring all WTO Members (or a critical mass) to undertake the specified level of commitments. 


\section{Pre-empting Protectionism in Services: The WTO and Outsourcing}

Cross-border trade in business services, especially the so-called "IT-enabled services", is today among the fastest growing areas of international trade. While the industrial countries are the largest exporters of such services, some of the most dynamic exporters are developing countries. Three factors are responsible for this phenomenon. First, advances in technology have made cross-border trade possible in a number of services that were previously only tradable through the movement of providers. Second, substantial investments in education in a number of developing countries have created a relative abundance of skilled labor, and the absence of commensurate employment opportunities has ensured its availability at a relatively low wage. Finally, innovations in business practice have led to the out-location of service activities by multinational enterprises in the manufacturing and services industry to offshore operational units or their outsourcing to foreign third-party service suppliers.

Even though these developments are creating a more efficient global division of labor and bringing significant welfare gains for all countries, they will inevitably affect the structure of employment in a number of importing countries and impose adjustment costs. The result is likely to be protectionist pressures, some signs of which are already visible. It is, therefore, desirable to take pre-emptive action and lock in the current state of openness. Accomplishing this would allow the world to continue to realize the substantial gains from trade, and ensure that adjustment costs are addressed through appropriate domestic policies rather than inferior trade restrictions.

The ongoing GATS negotiations offer a valuable opportunity to secure openness. The GATS framework will, however, need to be improved to deal with this most dynamic area of services trade - how precisely will depend on the level of ambition that is politically sustainable. Progress in this area will of course be linked to what happens in other areas of the services negotiations, which in turn depends on developments in the broader Doha agenda. The negotiations have lost momentum after Cancun, but the interregnum gives WTO Members time to reflect on the appropriate approach rather than simply continue with the request-offer process that has so far produced disappointing results.

A stocktaking of cross-border service activity, that must inform current GATS negotiations, is the subject of Section I. Section II critically assesses the suitability of the existing GATS framework for securing liberal market access. Section III describes two options that reflect varying levels of ambition in terms of the legal security they provide to current and potential services trade.

\footnotetext{
Cross-border IT-enabled services are services provided from one country to another over telecommunication or data networks; and are either externally contracted (outsourced) or provided by a remote subsidiary of the same company (off-shored/out-located).
} 


\section{Cross-Border Trade in Business Services: Dramatic Growth, Global Gains ANd Possible Protectionism}

We are dealing with a phenomenon that is hard to define and to quantify. First of all, there is no easy correspondence between the services that are being traded and existing service sector statistical classifications. Furthermore, this trade, by its very nature, is hard to measure - no customs officials record the passage of products and keeping track of the associated international financial transactions is difficult. Nevertheless, this section attempts to construct a rough picture based on available data.

Table 1: Information Technology and Business Process Outsourcing Services

1. INFORMATION TECHNOLOGY SERVICES (COMPUTER AND RELATED SERVICES)

Software Development and Implementation Services, Data processing and Database Services, IT Support Services, Application Development \& Maintenance, Business Intelligence \& Data Warehousing, Content Management, Eprocurement and B2B Marketplaces, Enterprise Security, Package Implementation, System Integration, SCM, Enterprise Application Integration, Total Infrastructure Outsourcing, Web Services (Internet Content Preparation, etc.), Web-hosting and Application Service Providers (ASPs)

2. Business Process Outsourcing

\begin{tabular}{|l|l|}
\hline $\begin{array}{l}\text { CUSTOMER INTERACTION } \\
\text { SERVICES }\end{array}$ & $\begin{array}{l}\text { Sales Support, Membership Management, Claims, Reservations for Airlines and Hotels, } \\
\text { Subscription Renewal, Customer Services Helpline, Handling Credit and Billing } \\
\text { Problems, etc. } \\
\text { Telemarketing and Marketing Research Services }\end{array}$ \\
\hline BACK-OFFICE OPERATIONS & $\begin{array}{l}\text { Data entry and handling, Data processing and database Services, Medical Transcription, } \\
\text { Payment Services, Financial Processing (financial information and data processing / } \\
\text { handling), Human Resource Processing Services, Payroll Services, Warehousing, } \\
\text { Logistics, Inventory, Supply Chain Services, Ticketing, Insurance Claims Adjudication, } \\
\text { Mortgage Processing }\end{array}$ \\
$\begin{array}{l}\text { MORE INDEPENDENT } \\
\text { PROFESSIONAL OR } \\
\text { BUSINESS SERVICES }\end{array}$ & $\begin{array}{l}\text { Human Resource Services (Hiring, Benefit Planning and Payroll, etc.), Finance \& } \\
\text { Accounting Services (including Auditing, Bookkeeping, Taxation Services, etc.), } \\
\text { Marketing Services, Product Design and Development }\end{array}$ \\
\hline
\end{tabular}

Sources: Own compilation based on information obtained from service providers (Internet pages), NASSCOM, and ITC (2000). The list of activities is neither exhaustive nor are the categories mutually exclusive.

The most dynamic area of services trade, and the bulk of the increased trade involving developing countries, is in information technology (IT) and business process outsourcing $(\mathrm{BPO})^{2}$ services. Table 1 provides a list of the most common outsourced or off-shored IT and BPO service activities. BPO services can be subdivided further into: "customer interaction services" (typically performed by call centers) and "back-office operations".

Table 1 reveals that the boundaries between IT services, customer care and other individual components are hard to draw. Even standard customer care functions often combine several activities, like the maintenance of a call centre, the use and update of customer databases, technical support, etc. To lump all these services into one category like "backoffice operations" does not do justice to the great variety of services being traded cross-border. Furthermore, as will be seen later, many of these services do not neatly fit into any existing

2 BPO (Business Process Outsourcing) can be defined as a contractual service to completely manage, deliver, and operate one or more (typically IT-intensive) business processes or functions. 
classification of services, which makes it harder to secure free cross-border trade through the GATS negotiations. One example is cross-border trade of organizational functions like payroll services by both the manufacturing and the services industries, and the ensuing slicing of the core service production into several segments ${ }^{3}$.

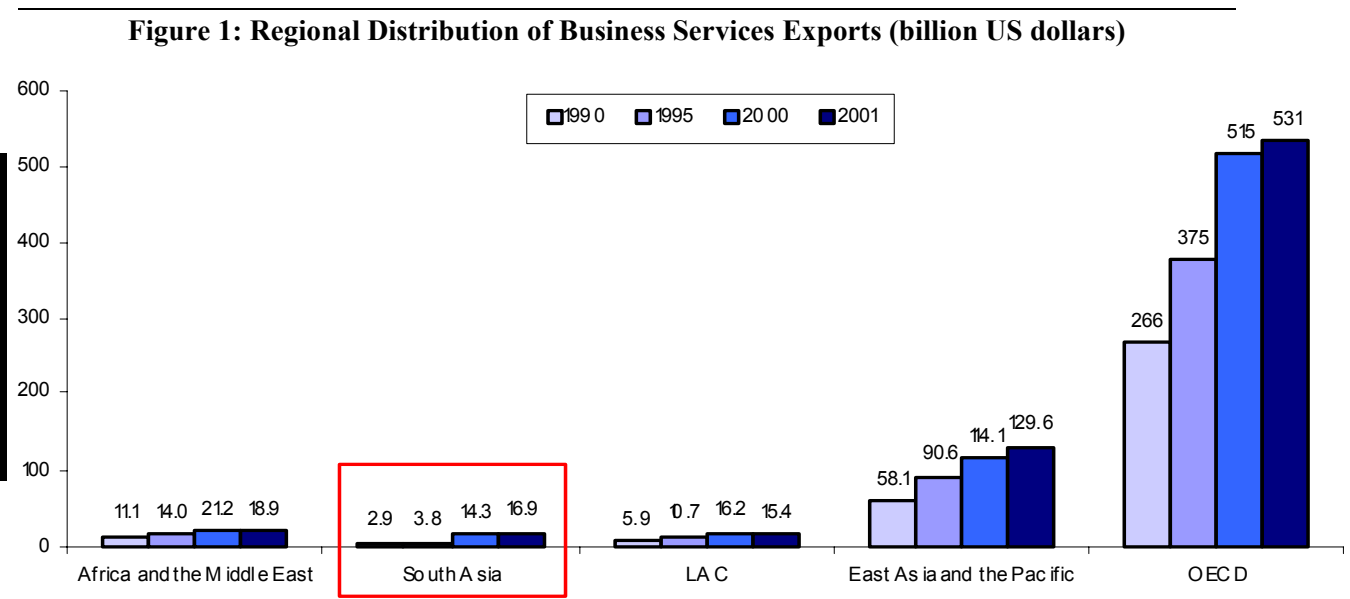

Source: IMF Balance of Payments Statistics; Note: -The "Business Services" category includes Total Services minus Transportation, Travel and Government Services. Alternatively, Business Services consist of: Communication, Construction, Insurance, Financial, Computer \& info, Other business, Personal, cultural and recreational services, as well as Royalties and License fees.

No reliable estimates are available for trade in business process outsourcing services, but the IMF Balance of Payments category business services covers trade in all services other than transport and travel services. As Figure 1 shows, most exports of business services still originate in OECD countries. But Figure 2 reveals that while the exports of the European Union and the United States have grown at respectively 6 and 11 per cent per annum in the second half of the 1990s, the exports of countries like India, Israel, Dominica and Brazil have grown at rates above 20 per cent per annum. Moreover, many other developing countries including Mauritius, Nicaragua, Barbados and China - have witnessed high rates of growth.

India has unquestionably been the leader, first developing a reputation as a premier location for software development, still its main cross-border IT-enabled service export. Two-fifths of the Fortune 500 companies outsource software requirements to India and work related to the year-2000 problem alone earned Indian companies $\$ 2.5$ billion $^{4}$. In 2002, India's IT industry grew 29 percent - faster than the growth of this industry in any other country. More recently, however, BPO services that provide intermediary inputs throughout the production process (for both goods and services) have grown much faster. While classical IT services, such as software development, grew last year by a 'mere' 22 percent, IT-enabled services such as outsourcing expanded by 65 percent $^{5}$. The latter typically involve India-based service operations providing an input or support service to the core activity/organizational functions of the importing company - e.g. WIPRO or GE Delhi provide payroll and customer care functions to the headquarters and affiliates of General Electric, GE.

3 Database entry or payroll services for instance are support services nearly all manufacturing and service industries draw on.

4 "Big companies look to India for software", in: Financial Times, July 3, 2000.

5 Financial Times (5 February 2003). 
This wide-spread outsourcing of non-core business processes by companies in industrialized countries is likely to have profound implications. Preliminary estimates suggest that the efficiency gains made possible by this global division of labor are remarkable. Through offshoring some of its customer-service activities to India, Prudential, the British insurance company, is planning to save $\$ 26.2 \mathrm{~m}$ through the creation of 1,000 customer-service jobs in India. ${ }^{6}$ The Pharmaceutical giant GlaxoSmithKline (GSK) plans to outsource all its global IT operations and experts expect savings of around 35 percent savings a year on the IT budget. ${ }^{7}$ General Electric saves about $\$ 350$ million per year through the 18,000 offshore employees it has in India. ${ }^{8}$ Studies suggest that the U.S. banking industry alone saved as much as $\$ 8$ billion in the last four years due to outsourcing ${ }^{9}$ and estimates on future gains (until 2009) for the overall U.S. industry range to U.S. $\$ 390$ billion, ${ }^{10}$ with $\$ 138$ billion in annual cost savings for the world's top 100 financial institutions. ${ }^{11}$ All in all, the savings figures usually range from 30 to 60 percent. $^{12}$

Whereas most industries have started to outsource operations because it allows them to significantly cut labor costs, they have also reported significant productivity gains, ranging from $15-25 \%$. As only around 5\% of U.S. firms with revenues from 100 million to 4 billion have started to outsource, much untapped potential for this sort of cost saving and productivity gains remain. The size of the outsourcing market will certainly grow when smaller and medium sized enterprises seek similar efficiency gains.

More specific estimates confirm the potential of BPO services. A survey by Deloitte Research, for instance, found that the world's 100 largest financial services firms expect to "transfer $\$ 350$ billion of their cost bases abroad" by $2008^{13}$. The value of medical transcription outsourcing in America alone is expected to double by 2005 to $\$ 4$ billion. ${ }^{14}$. The US market for 'contact centers' alone has a turnover of $\$ 100$ billion. $^{15}$

Given the enormous size and rapid growth of the BPO market, the economic implications for developing countries could be enormous. ${ }^{16}$ For example, if half of India's 50 million English-speakers were to eventually earn $\$ 10,000$ per year in IT-related services, this would more than double India's current GDP of $\$ 450$ billion $^{17}$. Given that IT-enabled exports tend

\footnotetext{
6 “ India fears impact of bid to curb jobs exports”, in: Financial Times, June 4, 2003.

7 "GlaxoSmithKline considers outsourcing deal", in: Vnuet.com, December 12, 2002.

8 “US firms saved \$8 bn via local outsourcing”, in: Business Standard, April 16, 2003

9 "US firms saved \$8 bn via local outsourcing", in: Business Standard, April 16, 2003

10 "U.S. gained \$17 b from outsourcing to India", in: Deccan Chronicle, July 7, 2003

11 "Looking for savings on distant horizons", in: Financial Times, July 2, 2003.

12 "U.S. gained $\$ 17$ b from outsourcing to India”, in: Deccan Chronicle, July 7, 2003, "Indian outsourcing cuts costs", in: vnunet.com, January 1, 2003, "The case for, and against, shifting backoffice operations overseas", in: Wharton Papers, October 9, 2002.

13 "The Cusp Of A Revolution - How Off-shoring Will Transform The Financial Services Industry”, Author: Chris Gentle, Deloitte Research, March 2003. According to another estimate, a typical bank can outsource 17-24 percent of its cost base.

14 The Economist (5 May 2001).

15 Financial Times (22 October 2002).

16 See "The New Global Job Shift: The next round of globalization is sending upscale jobs offshore", in: Business Week, Cover Story, February 3, 2003, "Call Centers: The Revolution Revs Up", in: Financial Times, March 10, 2003. "The Cusp Of A Revolution - How Off-shoring Will Transform The Financial Services Industry”, Author: CHRIS GENTLE, Deloitte Research, March 2003, U.S. firms move IT overseas, in: CNET News.com, December 11, 2002, by ED FRAUENHEIM.

17 Estimate on the number of English-speakers from: "Outsourcing to India: back office to the world," in: The Economist, May 5, 2001.
} 
to be associated with high levels of foreign direct investments, human capital formation, demonstration effects, and knowledge-spillovers, the indirect benefits might also be substantial.

There is every reason to believe that the comparative advantage of developing countries will not be limited to standard backoffice services. Already, cross-border service exports have evolved from lower-end, disentangled BPO services to more integrated, expert-based and web-enabled services. ${ }^{18}$ Companies have started to move up the value chain by focusing on innovation, consulting, branding and increasingly integrated services. In addition, more sophisticated cross-border trade activities like "Training/Online Education", "Product Design and Development Services" and "Technical Testing" are already being exported. Further changes in technology, the developing country skill set and business practices are bound to lead to cross-border trade in ever more sophisticated services. It is only a question of time before service suppliers in a number of developing countries move into more expert-based service areas ranging from professional services, $R \& D$ services to various health services. ${ }^{19}$

While such a transition is already underway in India, other developing countries with a similarly well-educated and relatively cheap work force will undoubtedly enhance their participation in this market. The rise in Indian wages - for example, wages in Vietnam or China are already said to be to be lower than Indian wages for comparable work - and the movement of Indian service suppliers to higher value analytical tasks is expected to bolster the trend. More generic, commodity processes will eventually move to lower cost environments. The phenomenon of globally fragmented production processes is bound to provide a powerful impetus to broader economic development.

A study by A.T. Kearney has compared the attractiveness of different countries as outsourcing locations (Figure 3). It confirms that while India remains overall the most attractive location, other countries are not far behind. Latin American countries offer low labor costs, proximity to the United States and are in the same time zone. Brazil's strengths include its large investments in information technology and telecom infrastructure and a large skilled labor pool. Companies such as Xerox and Unisys have committed to Brazil. Mexico offers the advantage of Spanish, a vital language for many US businesses. Since March 2002, AOL Time Warner serves its Spanish-speaking customers from a call center in Monterrey, Mexico - with estimated cost savings of 25-40 percent. The Philippines is an attractive location due to its cultural affinities with the United States, especially in terms of familiarity with US standards of service. For example, to take advantage of the large number of Filipino accountants trained in US accounting standards, Procter and Gamble moved the accounting services for its global operations to the Philippines more than three years ago. Other companies that have located in the Philippines include AIG, American Express and Citibank. China and Vietnam are also tapping into this service export possibility.

18 Multiple agencies such as telesales, call centers, data management, loyalty programs, etc. involve more technical expertise

${ }^{19}$ An A.T. Kearney study reveals that GE Capital International Services (GECIS) originated as a joint venture in India in 1997, offering basic financial transaction work and contract-center services. From 2001 to 2002, the company expanded to finance and accounting, complex transaction processing such as mortgage loans and insurance claims, and call centre services including outbound calls. More recently its service offerings have become even more complex, analytical and knowledge-based: conducting actuarial analysis, risk modelling, data mining and statutory financial reporting. 
From the perspective of a multinational that operates in Europe, it is Central European countries that offer cultural and linguistic similarities, greater ease of ensuring compliance with European regulations, e.g. pertaining to privacy, as well as high levels of technical ability. GE has become one of the largest investors in Hungary over the past 12 years moving a number of business processes to that country, in particular to support GE units across Western Europe. Russia too has a large pool of technical talent but needs to overcome difficulties created by weak infrastructure and language barriers. Boeing was the among the first companies to locate in Russia; today Russian aeronautics specialists in seven cities are designing parts on the 777 aircraft.

This optimistic scenario confronts one possible problem: political opposition in importing countries and pressure for trade barriers. What looks like a healthy job creation process in India and other developing countries may be seen as a "white collar job outflow" in the industrialized countries. The figures referred to above and other examples (e.g. forecasts that as many as 3.3 million jobs in the United States and 2 million jobs in western financial services will be lost over the next decade, and 200,000 in the United Kingdom by 2008; as well as more specific episodes, e.g. British Telecom announcing the creation of 2200 jobs in India at the expense of British call centers) are reportedly alarming some unions and politicians in the industrialized economies and political opposition is visible ${ }^{20}$.

Figure 3

${ }^{20}$ See "The New Global Job Shift: The next round of globalization is sending upscale jobs offshore", in: Business Week, Cover Story, February 3, 2003, "Call Centers: The Revolution Revs Up", in: Financial Times, March 10, 2003, "Services Go East", in: Financial Times, August 7, 2003. See Kirkegaard (2003) for a critique of these anecdotal figures and how they do not correspond to official data from the US Bureau of Economic Analysis. 


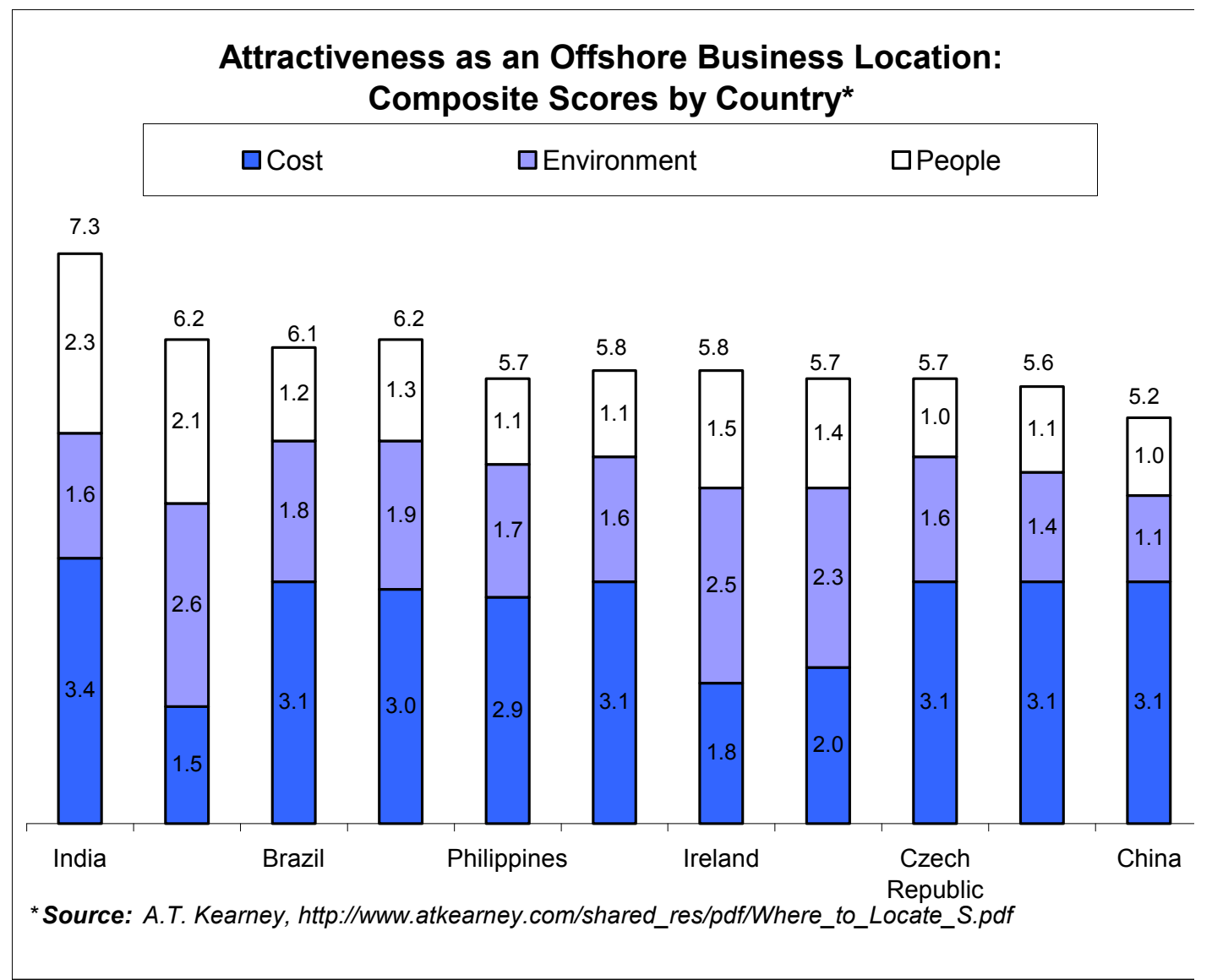

In fact, legislative action has already been initiated to create a trade barrier for BPO services. New Jersey State Senator Turner tabled a bill in September 2002 aimed at preventing the outsourcing of public work to Mumbai. ${ }^{21}$ Other US states like Connecticut, Maryland, Missouri, Wisconsin and latest Michigan are reportedly exploring similar legislation ${ }^{22}$. Recently, Indiana reportedly withdrew from a \$15 million contract with the US subsidiary of a leading Indian IT outsourcing firm. ${ }^{23}$ These restrictions on outsourcing only apply to government procurement and even though the size of government procurement markets of the U.S. and other industrialized countries is not small, such measures will not affect the bulk of BPO services that are conducted between businesses. But more importantly this move creates a dangerous precedent. It is possible that similar legislation, or even more likely, less transparent regulatory barriers, related to qualifications, labor standards, etc. may affect non-

${ }^{21}$ Senate Bill No. 1349, originally introduced on March 21st, 2002. See "U.S. States May Ban Contract Outsourcing", in: Financial Times, February 21, 2003. Since March $6^{\text {th }} 2003$, the Bill has been held in the Senate State Government Committee. See Senator Turner press statement of March $6^{\text {th }} 2003$, available at http://www.njsendems.com/Releases/03/March/Assembly\%20State $\% 20$ Govt $\% 20$ Comm $\% 20$ Holds $\% 20$ Turn er\%20Bill\%20to\%20Keep\%20Jobs\%20on\%20US\%20Soil,\%203-6-03.htm, accessed November 9 2003.

${ }^{22}$ See Eweek, March $10^{\text {th }} 2003$, Inside U.S. Trade June $20^{\text {th }} 2003$, p. 7, and Detroit News, Bill Bans State From Overseas Contracts, August $10^{\text {th }} 2003$.

${ }^{23}$ Governor Joe Kernan was quoted as saying that the contract did not fit with Indiana's vision of providing better opportunities to local companies and workers. See "Relocating the Back Office", in: Economist, December 13-19, 2003. 
government markets. In recent months, congressional activity in the US around the subject of job losses through outsourcing has intensified ${ }^{24}$. At the same time, in Europe, for example, legal norms designed to protect workers in outsourced deals, known as TUPE (Transfer of Undertakings and Protection of Employees) could also have an inhibiting effect on trade. ${ }^{25}$

Another issue that could have a profound effect on electronic commerce is privacy. In late 1998, the European Union issued a wide-ranging directive that aims to safeguard the privacy of personal data of EU citizens and prevent its misuse worldwide. It is backed by the power to cut off data flows to countries that the EU judges not to have adequate data protection rules and enforcement. The directive caused frictions with the US, which accused the EU of trying to impose laws beyond its own frontiers. A compromise was reached under which the US agreed to set up arrangements for the processing by companies of personal data from the EU, but the issue has not been fully resolved. The issue could have an impact on developing country exports of data processing services and confronts them with a difficult choice. If they choose not to enact laws deemed adequate, they could be shut off from participation in this growing market. In the absence of such laws and cumbersomeness of legal systems, it might be difficult for private firms to emulate United States firms and credibly commit to meet the required high standards. If they do enact stringent laws, then, unless the laws can be made specific to trade with particular jurisdictions, the result could be an economy-wide increase in the costs of doing business. ${ }^{26}$

In sum, the growing volume and scope of exportable services and the possibility of explicit and implicit protectionism towards outsourcing call for determined and innovative GATS negotiation strategies.

\section{THE INADEQUACY OF EXISTING INITIATIVES AND FRAMEWORKS}

The main achievement so far of the WTO E-commerce Work Program has been the decision on duty-free electronic commerce, whereby WTO Members have agreed to refrain from imposing customs duties on electronically delivered products. The renewal of this commitment is also an element of the draft Cancun Ministerial Text. It is ironic that considerable negotiation energy has been invested in prohibiting tariffs which no country imposes, do not seem feasible, and are at least a transparent instrument of protection. And little attention has been devoted to inferior and more feasible instruments of protection such as outright prohibitions of foreign supply and discriminatory internal regulation and taxation.

In any case, since the bulk of such commerce concerns services, the natural place for liberalizing commitments is under the WTO's General Agreement on Trade in Services

\footnotetext{
${ }^{24}$ House Small Business Committee hearing on June $18^{\text {th }}$ 2003, "The Globalization of White-collar Jobs: Can America Lose These Jobs and Still Prosper?”. In August 2003, the General Accounting Office, acting on letters from members of Congress initiated an official study of the impact of outsourcing on the US economy, expected to be released in the spring of 2004, and on October $20^{\text {th }}$ another hearing at the House Small Business Committee, entitled "The Offshoring of High Skilled Jobs," explored the trend of highskilled jobs being moved abroad. See KIRKEGAARD (2003) on looming US protectionism as a reaction to growing outsourcing.

25 Financial Times (5 February 2003).

${ }^{26}$ For instance, if private sector estimates generated in the United States are to be believed, information sharing saves the customers of 90 financial institutions (accounting for 30 percent of industry revenues), \$17 billion a year (\$195 per average customer household) and 320 million hours annually (4 hours per average customer household) (Glassman, 2000).
} 
(GATS). The GATS has many virtues. First, it explicitly includes cross-border trade as a mode of supplying services. Second, it provides a framework for countries to make specific commitments to maintain open trading conditions. These commitments, which must be negotiated, involve promises to grant market access (i.e. not impose any quotas or prohibitions) and national treatment (i.e. not to discriminate against foreign providers in any way). A full commitment from a country on market access and national treatment is a guarantee against most forms of protection - but not all, as we shall see below.

Specific commitments have additional value because several other GATS obligations apply to committed services. Examples are key elements of Art. VI on domestic regulations ${ }^{27}$, the Annex on Telecommunication Services ${ }^{28}$ and others ${ }^{29}$. Furthermore, full specific commitments can lead to the exposure and the subsequent reduction of regulatory barriers because GATS commitments provide the basis to challenge regulations that are being used for protectionist purposes rather than to serve a legitimate objective.

Even though the GATS is the natural home for liberalizing commitments on cross-border trade, the existing framework is far from ideal. One problem is that Members have not yet arrived at a satisfactory decision regarding whether electronic delivery of services should always be treated as cross-border trade or in some situations be consider consumption abroad, i.e. GATS mode $2 .^{30}$ To eliminate any uncertainty, it would therefore be necessary to obtain commitments with respect to both modes 1 and 2 .

A second problem is that since GATS commitments are undertaken according to a "positive list" approach for specified service activities only, it is not easy to ensure full coverage of a country's export interests by the commitments undertaken by trading partners. Most GATS Members made sectoral commitments on the basis of the so-called GATS Services Sectoral Classification List (so-called W/120 $0^{31}$ ). This list of 12 broad service sector activities ${ }^{32}$ prepared by the WTO Secretariat has independent subsectors that in most cases make numerical reference to the 1991 Provisional Central Product Classification (CPC) ${ }^{33}$. The $\mathrm{CPC}$ is both exhaustive and mutually exclusive ${ }^{34}$.

27 Art. VI 1: In sectors where specific commitments are undertaken, each Member shall ensure that all measures of general application affecting trade in services are administered in a reasonable, objective and impartial manner. New disciplines on domestic regulations are also likely to focus on areas where commitments have been made. The provisional disciplines under Article VI:5 hold only for service sectors and delivery modes where countries have scheduled trade commitments.

28 Para. 5 of the Annex on Telecommunication Services: Access to and use of Public Telecommunications Transport Networks and Services (a) Each Member shall ensure that any service supplier of any other Member is accorded access to and use of public telecommunications transport networks and services on reasonable and non-discriminatory terms and conditions, for the supply of a service included in its Schedule.

29 Article VIII Monopolies and Exclusive Service Suppliers 1. Each Member shall ensure that any monopoly supplier of a service in its territory does not, in the supply of the monopoly service in the relevant market, act in a manner inconsistent with that Member's obligations under Article II and specific commitments.

${ }^{30}$ For example, if a customer from the U.S. purchases a service from an Indian internet site, it is not obvious whether this should be treated as cross-border supply or consumption abroad. This classification issue is particularly relevant for financial and other regulation-intensive services because it has implications for determining the jurisdiction in which the transaction took place.

31 Named after the WTO document MTN.GNS/W/120 that contained this service classification.

32 1. Business; 2. Communication; 3. Construction and Engineering; 4. Distribution; 5. Education; 6. Environment; 7. Financial; 8. Health; 9. Tourism and Travel; 10. Recreation, Cultural, and Sporting; 11. Transport; 12. "Other".

33 The provisional CPC can be found in UN (1991). In a limited number of cases, the W 120 departs from the 
WTO Members are free to include only certain sectors of the less detailed W/120 in their schedules of specific commitments. They also have the choice of committing subactivities of a certain sector and omitting others ${ }^{35}$. Hence this scheduling methodology does not ensure that all current tradable services are covered. New services are only covered when they can be clearly identified under an existing sectoral classification that has been committed by the individual WTO Member State. When it is not clear if the new service really fits into a preexisting subcategory ${ }^{36}$ the applicability of commitments is - at best - uncertain. Because classification systems become obsolete fast the $\mathrm{CPC}$ was updated twice to cover the evolution of the economies and sustained technological advancement since the end of the Uruguay Round. $^{37}$ It remains to be seen how far the $\mathrm{W} / 120$ and the corresponding GATS commitments can respond to these developments.

In the present context, the key questions are whether the service sectors identified in Part 1 are mentioned in the GATS Services Sectoral Classification List and whether WTO Members have made the relevant mode 1 and mode 2 commitments. Unfortunately the status quo is far from satisfactory for two reasons.

- First of all, the GATS Service Sectoral Classification List does not always provide for an adequate description of the range of services under consideration (Section II.1).

- Second, there is considerable scope for improvement of GATS commitments by Members on the support service activities that best reflect the current structure of India's services exports (Second II.2).

\section{II.1 Inadequacy of the existing classification scheme}

If we begin with the more focused list of Indian IT and BPO service exports identified Table 1 , it is immediately obvious that many of the listed "input" or "support services" (for example payroll or customer care services) do not have a corresponding entry in the W/120. To see the problem more clearly, note that there are in principle two routes to ensuring coverage.

- The services could be covered by a self-standing W/120 category (Route 1), for example "Data processing services" ${ }^{38 ", ~ " S u p p l y ~ s e r v i c e s ~ o f ~ o f f i c e ~ s u p p o r t ~}$ personnel $^{39 ", "}$ "Telephone answering services ${ }^{40,}$, and "Provision and transfer of

provisional CPC.

34 This means that in principle all products are covered - with the "other" categories playing a vital role with regard to unspecified services - and if a product does not fit into a CPC category, it must automatically fit into another category. See UN (1991, 1998 and 2002) for more details on the CPC.

35 For instance among the "Computer and related Services"-category "Data base services CPC 844" is committed but "Data processing services CPC 843" is not.

36 E.g. call center services in "Telephone answering services CPC 87903" ? or new multimedia service in "telecommunication", "audiovisual" or "computer and related services"?

37 The CPC has been updated two times (CPC 1.0 in 1998 and CPC 1.1 in 2002) since the Uruguay Round ended. A further update is planned for 2007. Especially the CPC Version 1.0, published in 1998 paid particular attention to the elaboration of the services part of the classification.

38 CPC 843.

39 Supply services of office support personnel Services consisting in supplying on a fee or contract basis to the clients, whether on a temporary or long term basis, office support personnel hired by the supplier, who pays their emoluments. Included are the provision of personnel such as secretaries, clerks, receptionists, book keepers, data entry operators, typists and word processor operators (CPC 87203).

40 CPC 87903. 
financial information and financial data processing and related software by providers of other financial services ${ }^{41}$ ".

- It could be argued that commitments on input or support services which are not in themselves specified can be inferred from commitments on the final service (Route 2). For example, commitments on insurance services could be deemed to cover the services of call-centers that respond to customer queries about their policies, etc.

\section{Route 1: Services Directly Specified in the GATS Sectoral Classification List}

This search for direct correspondences does not produce a fully satisfactory result. On the positive side, several services in the existing W/120 classification capture many of the "support/BPO services". Thus, it is possible to put together a patch-work of certain Professional services; certain subactivities of Financial, Education, Library and Archive and Telecommunication services; all of Computer and Related Services; and all components of the "Other Business Services"-category (especially "Supply services of office support personnel", "Telephone answering services ${ }^{42 "}$ and "Other business services n.e.c ${ }^{43 ")}$ (see Model Schedule 3 for extracts of the detailed listing). Of course, since some support services consist of a bundle of services that are scattered through different W/120 categories, complete coverage would require commitments on each of the constituent services.

However, a more serious problem is that even this wide array of services does not assure coverage of a number of key support services in the W/120 classification. The problem remains regardless of whether we search for individual, self-standing categories or we look at services that may be listed as "auxiliary" or "incidental" to core service activities ${ }^{44}$. Even in the most likely home for self-standing listings, the "Other Business Service" Category, it is difficult to identify matching entries. For example, the activity of a call center (taking orders, soliciting contribution or providing information, technical support) is not captured even by an elastic interpretation of the "Telephone answering services" category. Similarly, it is difficult to find entries that capture medical transcription services, insurance claims adjudication, webenabled technical support services for an electronic equipment, or payroll services in the 12 year-old GATS classification system. The lack of detail in the category "other business service" sits awkwardly with the fact that this category has grown fastest in evolving classification systems like the CPC and in measured trade flows ${ }^{45}$.

Some uncertainties also arise because an overlap of new service activities between existing W/120 classifications. In the Committee on Specific Commitments, for example, India raised the example of web-hosting and application service providers (ASPs) that are a combination of various sub-sectors of CPC 84 on computer and related services and that also overlap with

41 7. B. 1. in the GATS Sectoral Service Classification (W120).

4287903 Telephone answering services:_Services consisting in the provision of telephone answering services. Included are telephone call forwarding services (excluding paging services), and telephone wake-up services.

43 t. Other 8790 is a catch-all category that has the potential to catch all other existing or arising business services that are not specifically addressed in the classification system.

44 Examples are: computer reservations systems (CRS) in the Annex on Air Transport, the provision of consulting services under the telecom classifications (CPC 75440), Services auxiliary to insurance and pension funding (CPC 8140), Supporting services for air transport (CPC 746), etc.

45 CAVE (2002), p. 8. 
neighboring services such as telecommunications ${ }^{46}$. This and other overlap cases are particularly problematic when the commitment level is very different for the alternative classification possibilities. It must also be clear that due to their increasingly integrated nature a commitment in one of these areas (database services, for instance) without a commitment in another area (market research and public opinion polling services) might not be worth much for certain BPO activities.

As described below, some of the lack in correspondence for support services is also attributable to the fact that even the most liberal GATS schedules have not used the full potential of the $\mathrm{W} / 120$ classification to commit categories that best match business support services. Especially residual catch-all categories that were designed to make the provisional CPC and the W/120 exhaustive were mostly not listed in schedules ${ }^{47}$.

\section{Route 2: Indirect Coverage As Inputs To Services Specified In W/120}

The situation does not improve if we try to "infer" input service commitments from commitments on main service classifications (e.g. commitment on insurance claims processing inferred from a commitment on Non-life insurance services). First of all, this inference procedure would not benefit goods manufacturers that rely on support services for their operations (e.g. billing, payroll services). Secondly, even for service suppliers, the coverage of input services is not legally certain.

The broad definition of the "supply of a service" of the GATS under Art. XXVIII(b) explicitly includes the production, distribution, marketing, sale and delivery of a service. Consequently, it could be assumed that all operational processes (e.g. payroll and billing) to support a service supplying organization are included if a commitment is made on a certain "final" service (e.g. financial services). Unfortunately, that interpretation does not prevail.

One undermining element of the "expansive" interpretation of certain specific commitments can be found in a small but significant footnote in the market access article of the GATS ${ }^{48}$. Its main message is even if a Member makes a full commitment on a particular service activity (no listing of limitations), it remains free to maintain measures that limit "inputs for the supply of a service". The interpretation of this footnote can have far-reaching implications with respect to the value of existing commitments.

A watertight interpretation of this limitation is difficult because the GATS itself does not use or define the meaning of "input for the supply of a service" in other part of the treaty. In fact as opposed to goods manufacturing processes - the dissociation of the "core service" and

46 Communication from India, S/CSS/W/141, 22 March 2002. With the new technologies many overlaps arise between the computer, the audiovisual and telecommunication services (e.g. multimedia content provision). But overlaps also arise between business and technology-related commitments in cases where for instance a special databank service is created and supplied for financial portfolio management for instance.

47 In practice, some of the corresponding entries are in residual categories of sub-classifications or catch-all categories that did not receive much attention during the Uruguay Round. As opposed to what it may suggest the W 120 category " 12 . Other Services not included elsewhere" $(95+97+98+99)$ is not a catch-all category for all services that could not be classified elsewhere.

48 Footnote 9 of the GATS" Subparagraph 2(c) does not cover measures of a Member which limit inputs for the supply of services" refers to GATS Art. XVI (2) on the scheduling of (c) limitations on the total number of service operations or on the total quantity of service output expressed in terms of designated numerical units in the form of quotas or the requirement of an economic needs test. 
"inputs for its supply" is particularly thorny. The GATS definition with regard to services is so broad because negotiators recognized this phenomenon of indivisibility of service transactions ${ }^{49}$. At the same time, negotiators were presumably keen to ensure that a liberalizing commitment on a particular service (say financial services) would not be taken to imply that a Member was obliged to allow liberal trade in all other services that were inputs in financial services, e.g. accounting and telecommunications.

That the latter concern dominates is confirmed by the new "Guidelines and Procedures for the Negotiations on Trade in Services" that are relevant for the ongoing GATS negotiations. These guidelines present the most expansive interpretation of footnote 9 It is stated that "It is understood that market access and national treatment commitments apply only to the sectors or sub-sectors inscribed in the schedule. They do not imply a right for the supplier of a committed service to supply uncommitted services which are inputs to the committed service." Consequently, support and input services must be scheduled and committed in an exhaustive manner to obtain legally certain market access and national treatment. Clearly, access for outsourced business support services that are not explicitly listed in commitments can hardly be taken for granted.

\section{II.2 Inadequacies of Existing GATS Commitments and Conditional Offers on Mode 1}

Several studies have examined in detail the level of commitments for cross-border supply of services ${ }^{50}$. In general, it is found that the commitments under mode 3 are much broader and deeper than the commitments under mode $1^{51}$. Many Mode 1 entries were left "unbound due to lack of technical feasibility" in the Uruguay Round but are now fully tradable. The more regulated a service sector is the less inclined governments were to fully open up trade for foreign service providers (e.g. in financial or professional services). This problem that has its roots in "regulatory precaution" exercised by governments applies heavily with respect to core services that are prone to complete electronic delivery ${ }^{52}$. In that sense the current market opening features of the GATS rather emulate a foreign investment agreement rather than allowing for trade in the traditional cross-border sense ${ }^{53}$. Moreover, commitments are generally more liberal with respect to consumption abroad (mode 2) than with respect to cross-border supply.

Table 2 shows the structure of Mode 1 commitments for all Members for a large set of service activities and thereby reveals that there is much scope for improving existing GATS Mode 1 commitments. It gives the total number of Members that have made commitments in a particular sector and distinguishes between three broad levels of commitments - full, partial and unbound.

49 The notion of an input to the service production is a modern concept recognizing a segmented service production value chain. It is doubtful however that during the Uruguay Round the contracting parties had such segmented service production in mind. Apparently, this restriction was originally introduced due to zoning and floor space laws that the Japanese wanted to be able to regulate.

$50 \quad$ See S/C/W/99, March 3, 1999, Background Note by the Secretariat, BACCHETTA, LOW, MATTOO ET AL (1998), Karsenty (2000), MAtToo \& SCHuKneCht (2001), p. 52 ff, OECD (2000) and Wunsch \& HAUSER (2002), p. 119-121.

51 WTO (2001), p. 8-9 and p. 104 ff.

52 See OECD (2000), GATS commitments and WTO (2001), p. 105.

53 HAUSER \& WUNSCH (2002). 
Table 2: Structure of GATS Commitments, all Members, Mode 1

\begin{tabular}{|c|c|c|c|c|c|c|c|}
\hline \multirow[t]{2}{*}{ Sector } & \multirow[t]{2}{*}{ Total $^{\mathrm{a}}$} & \multicolumn{3}{|c|}{ Market Access (\%) } & \multicolumn{3}{|c|}{ National Treatment (\%) } \\
\hline & & Full & Partial $^{\mathrm{b}}$ & Unbound & Full & Partial $^{b}$ & Unbound \\
\hline \multicolumn{8}{|l|}{ Business Services } \\
\hline Legal services & 59 & 20 & 60 & 10 & 20 & 60 & 14 \\
\hline Accounting/auditing/book-keeping & 70 & 34 & 41 & 24 & 37 & 39 & 24 \\
\hline Architectural services & 64 & 58 & 25 & 17 & 55 & 31 & 14 \\
\hline Medical \& dental services & 51 & 37 & 27 & 35 & 47 & 20 & 33 \\
\hline Software Implementation services & 71 & 61 & 24 & 15 & 65 & 17 & 18 \\
\hline Data processing services & 69 & 59 & 25 & 16 & 62 & 20 & 17 \\
\hline R\&D services (natural sciences) & 31 & 65 & 16 & 19 & 65 & 19 & 16 \\
\hline Advertising services & 54 & 57 & 31 & 11 & 57 & 24 & 19 \\
\hline Management consulting services & 65 & 63 & 23 & 14 & 69 & 18 & 12 \\
\hline \multicolumn{8}{|l|}{ Telecommunication services } \\
\hline Voice telephone services & 83 & 10 & 78 & 12 & 27 & 63 & 11 \\
\hline Private leased circuit services & 74 & 15 & 78 & 7 & 35 & 58 & 7 \\
\hline Electronic mail & 68 & 35 & 59 & 6 & 56 & 40 & 4 \\
\hline Online info \& data base retrieval & 70 & 34 & 55 & 11 & 59 & 32 & 9 \\
\hline \multicolumn{8}{|l|}{ Audiovisual services } \\
\hline Motion Picture Projection Service & 17 & 53 & 29 & 18 & 59 & 24 & 18 \\
\hline \multicolumn{8}{|l|}{ Distribution } \\
\hline Retailing services & 47 & 30 & 53 & 17 & 28 & 55 & 17 \\
\hline \multicolumn{8}{|l|}{ Educational Services } \\
\hline Adult education & 34 & 53 & 41 & 6 & 50 & 44 & 6 \\
\hline \multicolumn{8}{|l|}{ Financial Services } \\
\hline Insurance intermediation & 61 & 18 & 52 & 30 & 45 & 20 & 35 \\
\hline Lending of all types & 93 & 24 & 35 & 41 & 42 & 18 & 40 \\
\hline \multicolumn{8}{|l|}{ Health Related, Social Services } \\
\hline Hospital services & 41 & 44 & 2 & 54 & 51 & 2 & 46 \\
\hline \multicolumn{8}{|l|}{ Tourism Services } \\
\hline Travel agencies & 103 & 54 & 18 & 27 & 59 & 15 & 26 \\
\hline \multicolumn{8}{|l|}{ Recreational Services } \\
\hline Entertainment services & 39 & 51 & 10 & 38 & 54 & 10 & 36 \\
\hline News agency services & 24 & 71 & 21 & 8 & 63 & 33 & 40 \\
\hline
\end{tabular}

Source: Based on data provided by the WTO Secretariat, updates S/C/W/99, March 3, 1999

${ }^{a}$ Total number of Members with commitments in Mode 1.

${ }^{\mathrm{b}}$ Includes horizontal limitations.

In general the commitment level across WTO Members and service sectors is quite heterogeneous. In Table 2, commitments range from 17 commitments for motion picture projection services to 103 commitments on travel agencies. Only a few service sectors are committed by at least two-thirds of WTO Members. To give some examples, in 2000 only few service sectors particularly amenable to electronic transactions (other business services, professional services, financial services) had commitments by significantly more than half of the WTO membership ${ }^{54}$. But except for some business services (i.e. advertising and management consulting services), the GATS Mode 1 commitments on these three rather liberal service sectors are often only partial commitments. In some sectors, nearly two-thirds of the commitments guarantee full market access (i.e. news agency services) whereas in others, like voice telephone services, most commitments are of a partial nature. Accordingly, the lack of mode 1 commitments also applies to the most liberal sectors like business and computer services that - due to their generally low level or regulation - are known to be

54 See Mattoo \& SchuKneCht (2000), p. 14 and Mattoo \& SchuKnECHT (2001), p. 17. 
relatively well-covered by GATS commitments ${ }^{55}$. In "Accounting, auditing and bookkeeping" and "Data processing", for example, only 70 and 69 Members, respectively, have made commitments. In accounting the majority of the 70 Members enters some limitations to free market access and national treatment, while in data processing only around two-thirds of these commitments guarantee unrestricted market access. In other sectors that can be subject to electronic transactions (audiovisual, education, health, education, recreation, etc.) the number of commitments is even more limited. Audiovisual services has received only 19 whereas adult education has received 31 commitments.

The scheduled limitations to the cross-border supply do not vary much across sectors and are few enough to be enumerated. Specifically, nationality, residency, commercial presence, authorization, licensing and local authentication requirements constitute the majority of cross-border service trade barriers ${ }^{56}$. These limitations aim to heavily restrict, if not outright prohibit, the cross-border supply of services. Few quantitative market access limitations have been entered but a significant amount of national treatment limitations exist on cross-border supply. Annex Table 1 lists some of these restrictions.

If we focus on the support and BPO services that developing countries are supplying, the picture is hardly more positive. The lack of a proper classification scheme that would allow GATS Members to schedule comprehensive commitments on BPO services is only part of the story. Annex Table 2 presents the state of commitments on a patchwork of existing $\mathrm{W} / 120$ entries that correspond to some of the BPO services. Whereas for instance, the most liberal GATS schedules almost always include full commitments on data processing, they offer surprisingly little in some of the categories that are likely to be the most important ones to guarantee full market access for BPO and support services ("Supply services of office support personnel, Telephone answering services, Other business services n.e.c.").

Table 3 concentrates on a few industrialized and large developing countries. It is striking that the few opportunities to at least use the limited W/120 and the underlying provisional CPC to schedule broadly with respect to business support services were not taken even in the most liberal GATS schedules ${ }^{57}$. Even more worrying is the fact that the ongoing GATS negotiations have - so far - not yet been used to go further in this respect. By June 2003 around one-third of the WTO Members had extended initial requests to some of their fellow trade partners ${ }^{58}$. By January 2004 initial offers have been presented by some 40 Members ${ }^{59}$. Column 3 of Table 3 assesses the few initial and publicly available services offers (namely, Australia, Canada, EC, Japan, New Zealand, Norway, U.S. and Switzerland). It emerges that these Members (exclusively industrialized countries) did - with two minor exceptions - not improve their GATS schedule for the items under consideration. In fact, only Canada has nearly full commitments in all three relevant categories.

55 Computer and Related Services, WTO Document S/C/W/45 14 July 1998

56 OECD (2000), p. 6 ff. Thanks goes to Rachel Thompson for this extremely comprehensive work.

57 The exception to the rule is the Canadian GATS schedule.

${ }^{58}$ Noted by Bridges “Only Few Services Offers Trickle in By End-March Deadline”, in: Bridges Weekly Trade News Digest, Vol. 7, No. 12, April 2, 2003.

59 Argentina, Australia; Bahrain; Bolivia, Canada; China, Chile, Chinese Taipei; Colombia, Czech Republic; European Communities and its Member States; Fiji Islands; Guatemala, Hong Kong, China; Iceland; Israel; Japan; Republic of Korea; Liechtenstein; Macao; China; Mexico; New Zealand; Norway; Panama; Paraguay; Poland; Slovenia; St Christopher and Nevis; Senegal, Singapore, Slovak Republic, Slovenia, Sri Lanka, Switzerland; Thailand, Turkey, United States and Uruguay. 
Other than in areas where new ground was covered with more radical approaches (e.g. energy or express delivery services) the changes in the offers involve mostly the elimination of scheduled limitations rather than the creative scheduling of new subcategories ${ }^{60}$. In some cases Members went further:

- The U.S. which does not schedule commitments with CPC references, listed and committed to more detailed subsectors like Advertising services and the Placement and supply services of personnel.

- Some have committed more broadly (eliminated restrictions) for certain W120 sectors and subsectors but also indicated that only part of certain CPC definitions or activities covered by W 120 categories are included (e.g. Canada for Computer and related services subcategories such as Data processing services).

- In some categories some Members have eliminated a listing of "unbound due to lack of technical feasibility and converted that into a binding of "none" (e.g. Canada for "Storage and Warehousing Services under Maritime Auxiliary Services").

So although in many sectors it was debated what subactivities and what classification schemes should be used to better reflect current economic realities ${ }^{61}$, in general the approaches taken in the initial GATS offers were, so far, eclectic rather than comprehensive.

It is in only the few sectors where some Members have made commitments on the higher two- or three digit level that there is exhaustive coverage of existing and new services (e.g. the EC's schedule is accompanied by an Understanding on Computer Services that intends to define the scope of the two-digit category). Also only a few have added individual CPC- / W 120 -subcategories that were not committed to previously (e.g. Australia for the "Protection of biodiversity and landscape" in the environmental service column).

Clearly, the weaknesses in classification and commitments in many "Other business services", which vitally affect the coverage of support services, have not yet been addressed (see Table 2) ${ }^{62}$. The existing classification possibilities of the provisional CPC have - againnot been used to their fullest extend to reflect other business services ${ }^{63}$. No updates were taken along the lines of the new CPC 1.1 classification scheme to better reflect the current economic realities (no entry for telemarketing, no entry for payroll services, no new notion of "Business Support Services" as defined in Division 84 of the CPC 1.1).

\section{II.3 Stocktaking}

Existing commitments do not match current cross-border service exports, and are quite far from covering potential exports. Even new commitments that may result from the ongoing negotiations will not adequately cover the vital category "support" services and new services as long as the provisional CPC is used for scheduling purposes.

60 In fact the GATS requests themselves mostly operated within the 1991 framework (e.g. asking for the elimination of listed limitations and asking for the scheduling of uncommitted W 120 categories).

61 Primarily in the Committee on Specific Commitments.

62 Canada is one of the few that already had most comprehensive commitments under the "Other business service" classification.

63 Few or no new commitments on "t. Other (CPC 8790)" and other catch-all categories. 
The underlying CPC classification has been revised two times already ${ }^{64}$. Without doubt, the current CPC 1.1 provides a much closer fit to economic reality than does the W/120. In particular, the new Division 85 tailored for Support Services specifies activities like "Telephone Call Center Services" (CPC 1.1 85931), and provides a much more accurate picture with regard to "input services". As Members are free to change their classification references or to refer to own service activities as long as commitments are not diminished ${ }^{65}$ the use of the updated CPC 1.1 would certainly provide more legal certainty.

But does even a switch from the provisional CPC to the updated CPC 1.1 guarantee that future support and core services will be covered? The answer is a simple "No". Even the most complete classification scheme will not be able to foresee future service activities. By definition static classification systems always run behind trade realities ${ }^{66}$. As a result, at their very best, updates to classification systems and trade negotiations with a positive list approach can only try to "catch-up" to arising service trade possibilities ${ }^{67}$.

In this area, where technological development and business innovation are rapidly changing the spectrum of services, frequent and resource-intensive negotiations would be required to secure liberal conditions for current and future service trade. Furthermore, without a coherent approach individual Members may resort to their own sub-sector definitions or to different classification schemes. In fact the "Guidelines and Procedures for the Negotiations on Trade in Services" impose virtually no limits on the heterogeneity of classifications that could be introduced $^{68}$.

64 See UN (1998) for the CPC 1.0 and UN (2002) for the CPC 1.1.

65 Incorporation of Commitments Resulting From Current Services Negotiations Into Members' GATS Schedules, S/CSC/W/33, June 3, 2002, Committee on Specific Commitments, Note by the Secretariat

66 See Cassamajor (2002), Cave (2002) and Becker (2001) on this point and for a description of how the CPC is updated. Becker notes that "The development and maintenance of (economic) classifications is an eternal struggle between two large forces: those who want to keep the classification as updated as possible to quickly respond to all kinds of changes in the economy, and those who want to keep the classification as stable as possible over a long period of time to ensure comparability of data and consistency of time series".

67 Obviously the cycle of service trade negotiations (the GATS 2000 Round started 5 years after the entry into force of the Uruguay Round) and the involved difficulties in updating classifications / commitments have a negative impact on the match between commitments and economic realities.

68 S/L/93, March 29, 2001, Adopted by the Special Session of the Council for Trade in Services on 28 March 2001 
Table 3: State of Existing Commitments and Conditional Offers on Selected BPO-Related Services

\begin{tabular}{|c|c|c|}
\hline & UNBOUND IN THE URUGUAY SCHEDULE & $\begin{array}{l}2003 \text { INITIAL GATS OfFERS From AUSTRALia, } \\
\text { CANADA, EC, JAPAN, NeW ZEALAND, NORWAY, } \\
\text { U.S., SWITZERLAND }\end{array}$ \\
\hline \multicolumn{3}{|c|}{ Backoffice Operation Categories under F. Other Business Services } \\
\hline $\begin{array}{l}87203 \text { Supply services of office support } \\
\text { personnel }\end{array}$ & 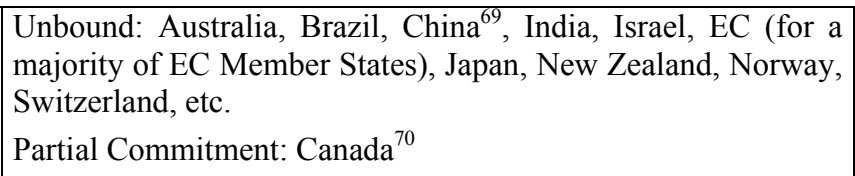 & $\begin{array}{l}\text { No improvement in commitments for these seven } \\
\text { WTO Members except for New Zealand }\end{array}$ \\
\hline \multicolumn{3}{|l|}{ t. Other 8790} \\
\hline 87903 Telephone answering services & $\begin{array}{l}\text { Unbound: Australia, Brazil, China, India, Israel, EC (for all } \\
\text { Member States), Japan, New Zealand, Norway, Switzerland, } \\
\text { USA, etc. }\end{array}$ & $\begin{array}{l}\text { No improvement in commitments for these seven } \\
\text { WTO Members except for Japan }\end{array}$ \\
\hline 87909 Other business services n.e.c. & $\begin{array}{l}\text { Unbound: Australia, Brazil, China, EC (for all Member States), } \\
\text { Japan, New Zealand, Switzerland, USA, etc. } \\
\text { Partial Commitment: Norway }\end{array}$ & $\begin{array}{l}\text { No improvement in commitments for these seven } \\
\text { WTO Members }\end{array}$ \\
\hline
\end{tabular}

Remark: This table is not an comprehensive analysis of all WTO Members. We draw from some schedules of industrialized economies (as defined by the GATS Database on Commitments of the WTO Secretariat) and a few large developing countries. The comparison of the initial offer with the Uruguay schedule is only possible where WTO Members have handed in GATS initial offers that were available to us as of July 15, 2003.

69 Accession schedule.

70 Commercial presence requirement for Ontario.

71 U.S. had a binding of "none" and has now specified in greater detail what sub-activities are covered by this commitment.

72 Canada had a binding of "none".

73 Canada had a binding of "none". 


\section{OPTIONS To SECURE OPENNESS OF CROSS-Border TRADE IN SERVICES}

The limited coverage of key service activities (both in the classification as well as the commitments) is likely to be a concern to all countries that seek to secure liberal conditions for trade in their area of comparative advantage. But for negotiators to extract commitments sector by sector, trading partner by partner is likely to be difficult and involve high transactions costs. Furthermore, as we saw above, the initial GATS offers that have been made public by industrialized countries with relatively liberal GATS schedules (U.S., Australia, Canada, EC) support the view that incremental solutions are unlikely to be adequate.

As countries seek improved access for their exports, they must determine the appropriate approach to international negotiations, and choose in particular between two alternatives. One is a bilateral request-and-offer approach, the other is the use of generally applicable negotiating formulae or model schedules. In the sphere of trade in goods, governments have sometimes agreed to a formula on the basis of which they cut tariffs across-the-board by a uniform amount. Francois and Martin (2003) document how previous rounds of negotiations that used formula based approaches to goods trade liberalization (such as the Kennedy and Tokyo rounds) produced far deeper liberalization than other rounds that used less welldefined approaches.

With a few notable exceptions - model schedules for maritime transport and telecommunications, the understanding on financial services and the reference paper in basic telecommunications - formulae have proved difficult to design for services negotiations because many different non-quantifiable instruments affect access to markets. Moreover, developing countries have supported the request-and-offer approach because it allows considerable freedom to decide on how much to liberalize. There might, however, be a case for a more aggressive approach in modes 1 and 4 where developing countries have a comparative advantage.

There seem to be four broad reasons to favor formulae/model schedules. First, in a world of unequal bargaining power, multilaterally agreed formulae that must be seen to be equitable and efficient are likely to produce a more favorable outcome for the weaker party than bilateral negotiations. Second, formulae help reduce the transactions costs of negotiations avoiding the need to barter commitments sector-by-sector, country-by-country. Thus, formulae can help overcome the difficulty in accomplishing an exchange (and balance) of concessions between countries that do not necessarily have a reciprocal interest in each other's markets. This, of course, assumes that the negotiation of formulae itself does not involve large negotiating costs. Third, formulae can help overcome the free-rider problem that arises in negotiations conducted under an MFN-based system. The problem arises in bilateral negotiations because each of the beneficiaries of a concession from a trading partner may be tempted to understate their willingness to pay for it, hoping that offers of reciprocal concessions from other Members will be sufficient to induce the concession. If each Member behaves in this way, the result could be that mutually beneficial deals will not be struck. Finally, the use of multilaterally applied formulae is perhaps the only credible way of granting credit to the unilateral liberalizers. In contrast, it is much more difficult to ensure compensation for the loss of negotiating coinage caused by unilateral liberalization in a bilateral request-and-offer negotiation. 
It may be possible to develop formulae or model schedules for concerted or more coordinated approaches to liberalization, such that WTO Members end up making more far-reaching commitments on these modes. At the very least, the market access and national treatment commitments must capture the services depicted in Table 1 (Option 1 below). But limiting the negotiating focus to a few IT and simple BPOs can only follow from an unjustifiably static view of international trade in services. Besides it will not be easy to anticipate the full range of services that could be supplied cross-border, and how they relate to the existing classification of services used for scheduling purposes (especially input or BPO services). WTO Members may therefore consider whether it is feasible and desirable to obtain full commitments on cross-border trade on the widest possible range of services. How this may be accomplished while respecting national regulatory concerns is discussed under Option 2 below.

\section{Option 1: Targeted Commitments for Cross-Border Trade in IT and BPO Services}

This option presents a targeted approach to ensure free cross-border trade in a selected set of IT and BPO services. Under a model schedule (see below) Members would be expected to make full market access and national treatment commitments on the positive list of services. The service categories are specified in their most aggregate form (two-to-three digit level) in order to include all possible sub-activities. The selected categories include directly identified business services, as well as elements of other services, such as bookkeeping and auxiliary financial services, which are increasingly outsourced. Annex Table 2 shows the current state of commitments with respect to these services.

It is important to understand that the model schedule takes a nuanced approach. For example, while it proposes full GATS mode 1 and 2 commitments on all computer and related services at the highest, two-digit, level, with respect to telecommunication services, it proposes only a full commitment on online information and data processing services that are relevant to BPO services. In the regulated professional services full commitments are proposed only with respect to accounting, auditing, bookkeeping and taxation services. Most commitments would have to be undertaken in the other business service category which - taken together - covers most BPO Services. For completeness of the business service commitments, the model schedules adds market research/public opinion polling services, management consulting services, services related to manufacturing, consulting, technical testing and analysis services, related scientific / technical consulting services and finally printing and publishing services.

The schedule takes a more limited approach to education, financial and recreational services. Specifically, it proposes only two education services that are not central to public education systems - adult education and other education. In the same vein, the schedule only asks for commitments on one particular insurance and two specific banking services ${ }^{74}$. None of these services entail capital mobility and thus avoid a sensitive area of policy. Finally, the recreational services "library and archive services" is included because this category covers

\footnotetext{
${ }^{74}$ Services auxiliary to insurance are services closely related to the management of insurance and pension funding (i.e. insurance, financial and pension consultancy services, evaluation and adjustment services of insurance claims, actuarial services, etc.). The banking services included are the provision and transfer of financial information and financial data processing and related software by providers of other financial services and other services auxiliary to financial intermediation (financial consultancy services, other services auxiliary to financial intermediation).
} 
documentation services, i.e. collection, cataloguing, conservation and retrieval services of documents that some BPO services are likely to involve.

Finally, Members would also need to update their schedules with commitments on the basis of the revised CPC 1.1 classification. Especially the category "Support services" as defined in CPC 1.185 and the categories "On-line information provision services" CPC 1.1 843, and "Licensing services for the right to use non-financial intangible assets" CPC 1.1733 seem particularly relevant.

This model schedule ensures a reasonable degree of coverage of a range of existing service activities, and would probably cover a large part of current trade in IT and BPO services. It also has the virtue of being consistent with Members' revealed preference for gradualism. This incremental approach does not take Members out of the confines of current scheduling practice or current classification systems, with minor modifications. This approach could also provide the basis for consultation with the service industries themselves on the additional sub-categories that must be covered to ensure flexibility in reorganizing their production and slicing their business operations in a climate of legal security.

But the approach does have several disadvantages. First of all, it probably does not cover a number of services that are being traded today. Second, by operating within the confines of a static classification scheme it certainly will not cover a range of new services that will be traded tomorrow, and may thus be reinforce the image of the GATS as operating one step behind trading reality. Finally, this option covers only standard IT and BPO services and does not ensure security of access for a range of professional and other services that may be traded cross-border, and in which countries like India have a growing export interest. 
Model Schedule 1: Targeted Specific Commitments for IT and BPO Services

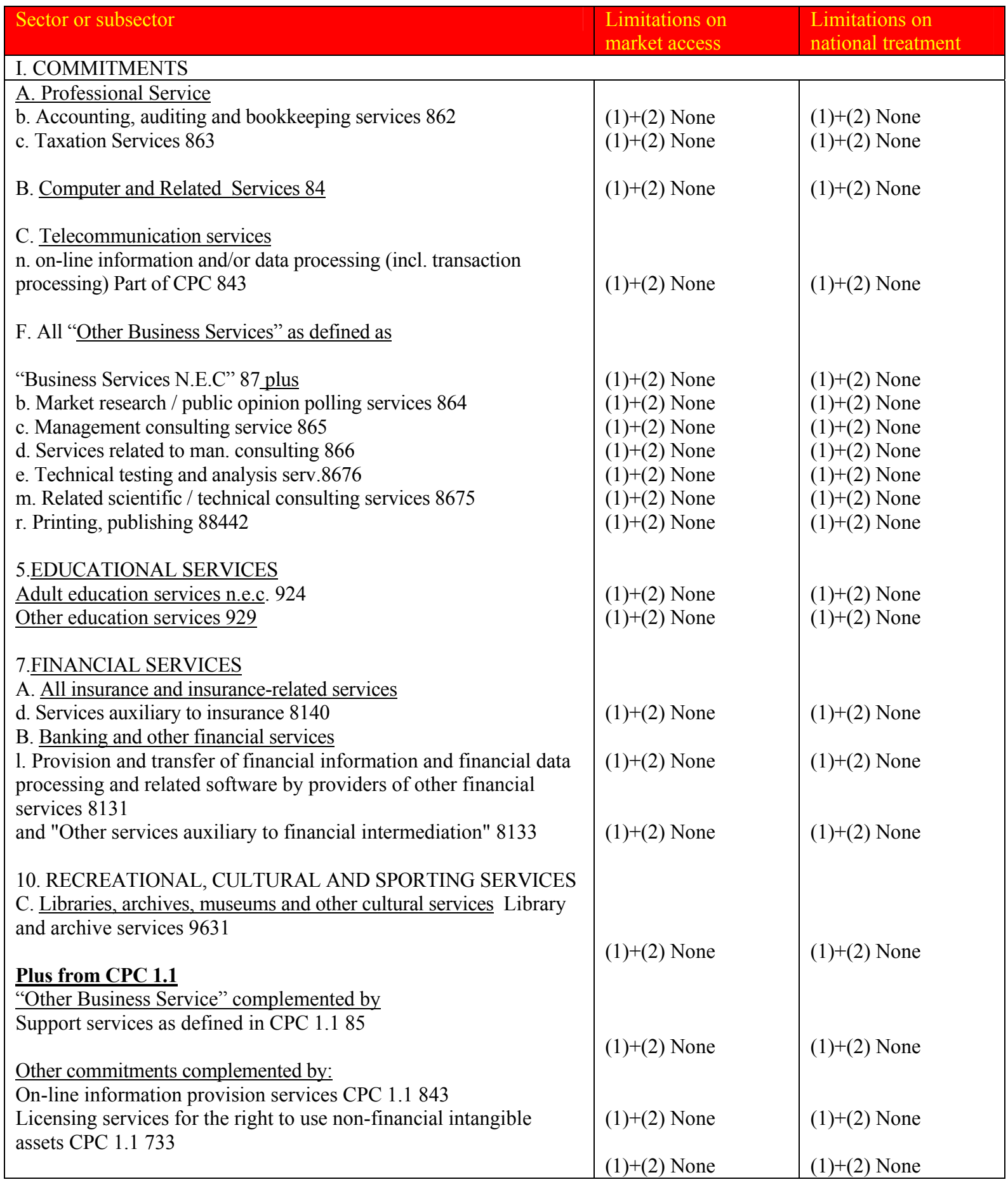

\section{Option 2: A Horizontal Commitment to Liberalize Cross-Border Trade in a Wide Range of Services}

The limitations of the previous option suggest that Members may wish to consider a more coherent and forward-looking approach. The approach is ambitious, but it has the potential to 
move cross-border service trade liberalisation through the GATS into a new dimension. It is best summarized by the following model schedule entry.

\section{Model Schedule 2: Horizontal Commitment to Liberalize All Cross-Border Services}

\begin{tabular}{|l|l|}
\hline \multicolumn{2}{|c|}{ Modes of supply: 1) Cross-border supply, 2) Consumption abroad, 3) Commercial presence } \\
4) Presence of natural persons
\end{tabular}

Through such a horizontal commitment a WTO Member would effectively commit to provide market access and national treatment to all services supplied on a cross-border basis (crossborder supply and consumption abroad). An important difference from the usual horizontal commitments is that this commitment would be understood to apply to all services and not only those listed in the individual schedule. It would also be understood that commitments apply both to services that exist at the time that commitments are made and to any new services that are introduced in the future.

This broad forward-looking commitment could be accompanied by a closed list of exceptions. The two exceptions suggested here are financial services that involve the movement of capital and transport services that involve the movement of freight or persons. These sectors are clearly different from other services that can be traded cross-border electronically. As opposed to BPO services where only bits travel across borders, financial and transport services entail the movement of capital, goods and people, that has very different and more complex implications (including capital account liberalisation). One possibility with regard to financial services is to adopt the same coverage as in the Understanding on Financial Services, i.e. cross border trade in insurance of risks relating to international transport would be covered but not in other forms of life and non-life insurance, services such as the provision and transfer of financial information and financial data processing would be covered, but not the acceptance of deposits or lending by banks abroad. This is not to say that eventual liberalization in all financial and transport services is not desirable, but merely to recognize that at this stage the best should not be the enemy of the good: the task of locking in mostly open cross-border trade in electronically delivered services would be difficult to accomplish if it were linked to the much more demanding task of eliminating entrenched barriers to trade in financial and transport services.

Apart from this list of exempted services, Members would commit to all other current or future service activities for the GATS mode 1 and 2 (including support services). This would amount to an advance with respect to these two modes over the negative list approach 
increasingly used in the process of regional service liberalization ${ }^{75}$ - because the list of exceptions would be pre-defined and closed rather than subject to negotiations.

In principle, this presents a significant move toward securing the liberalization of crossborder services. As Members bind across the board and eliminate the existing limitations for GATS Mode 1 and Mode 2, they give up the right to maintain or introduce new restrictions. In practice, however, not much would change today because many covered services are already traded freely. Though Members were reluctant to bind mode 1, only a few limitations were listed in the Uruguay Round, some examples of which are presented in Annex Table 1. One class of limitations are examples of regulatory precaution - e.g. the requirement for foreign providers to obtain permission or recognition - which is in principle not necessary to schedule but Members have erred on the side of caution. Another class of measures are more ambiguous in intent and effect - e.g. the requirements for foreign providers to be established or be resident. They could be necessary to achieve the regulatory objective of protecting consumers or they could be protectionist, as can only be established on a case-by-case basis. This issue is discussed in more detail below. A third class of limitations reflects explicit protection, e.g. the persistence of monopoly in insurance or basic telecommunications, or discriminatory treatment of foreign services through taxes or subsidies. In these cases, the proposal would require the elimination of existing restrictions and have a liberalizing force that goes beyond the locking in of openness.

The extent of actual market-opening depends on whether these restrictions can actually be enforced at all or partly in an online environment given the current state of technology. If for instance a foreign consultant gives management advice over the phone or if a foreign architect sends a blueprint for an office building via email, regulators may not have the ability to track and regulate these cross-border service flows. The same holds true for many computer services and even financial services. Even the well-guarded audiovisual quotas that the EC maintained in the offline world are impossible to enforce for the Internet. The role of the commitments would then be to preclude restrictions if they were to become feasible.

To see the implications of the suggested approach, it can be usefully compared with the Canadian GATS schedule of 1994 (and the current offer) which included a similar but somewhat more restrictive horizontal commitment on full market access and national commitments under GATS mode 1 and $2^{76}$. There are two major differences with the proposed approach. The Canadian horizontal commitment is meant to apply to scheduled services only ${ }^{77}$. This qualification creates a renewed dependence on the classification scheme employed and the need for comprehensive scheduling of all services. But more importantly, the Canadian horizontal commitment allows for deviations in the form of sector-specific limitations. As a consequence this "horizontal" commitment is much less radical and far reaching than it first seems. ${ }^{78}$

STEPHENSON (2002).

76 Except for a limited number of very specific (sometimes of a regional nature) horizontal limitations to the national treatment obligations.

77 Although the Canadian schedule does not indicate this limited application of the horizontal commitments this interpretation can be inferred from para. 36 of the GATS scheduling guidelines that indicates that a horizontal commitment applies to trade in services in all scheduled services sectors unless otherwise specified.

78 In the sense that dropping it from the Canadian GATS Schedule would not reduce or increase the rights or obligations of the Canadian government. To illustrate: The horizontal commitment does not apply to "Other Business Services" that the Canadians have not explicitly scheduled 
Would such a "radical" approach be acceptable to WTO Members who have revealed a reluctance to make binding commitments on cross-border trade, especially in regulationintensive services? Consider three variants of the approach that provide varying degree of reassurance to national regulators.

Option 2a: Model Schedule 2 as is

The boldest view is that specific commitments under the GATS must not deprive Members of legitimate regulatory freedom, and so the version presented above should be generally acceptable. Both the GATS itself ${ }^{79}$ and the GATS Negotiation Guidelines ${ }^{80}$ recognize the right of Members to regulate, and to introduce new regulations on the supply of services. The assumption of specific commitments under GATS Art. XVI and XVII does not prevent governments from regulating services or service suppliers for quality or other reasons. As the new GATS Scheduling Guidelines reaffirm, regulations of a non-discriminatory nature, applied equally to nationals and foreigners, must not be scheduled under Art. XVI nor $\mathrm{XVII}^{81}$. Minimum requirements such as those common to licensing criteria (e.g. minimum capital requirements for the establishment of a corporate entity) do not fall within the scope of Article XVI. Finally, all measures falling under the broad list of General Exceptions of the GATS $^{82}$ must not be scheduled and can be maintained if they are not applied in a manner which would constitute a means of arbitrary or unjustifiable discrimination between countries (which would cover measures designed to ensure data privacy, prevent fraud, etc.).

Consequently, full market access and national treatment commitments only make sure that relevant domestic regulations cannot be used to discriminate deliberately against foreign service suppliers (principle of equal treatment akin to EC law Art. 59). "Like services" from national and foreign service suppliers would then face the same regulatory requirements. Examples of measures that would not be allowed under full commitments are nationality or residency requirements, and licensing and qualification requirements that do not serve a legitimate regulatory objective and seek only to protect national providers. Governments could of course continue to maintain and enact non-discriminatory legislation relevant to the service sector.

This approach, nevertheless, has wide-reaching systemic implications for unfettered crossborder trade of services and GATS dispute settlement. It can help ensure that all remaining regulations are not of a discriminatory nature (except if they fall under GATS Art. XIV and comply with its chapeau) and help make regulations more trade friendly. ${ }^{83}$ At the same time,

79 See the Preamble to the GATS: Recognizing the right of Members to regulate, and to introduce new regulations, on the supply of services within their territories in order to meet national policy objectives and, given asymmetries existing with respect to the degree of development of services regulations in different countries, the particular need of developing countries to exercise this right.

80 "Guidelines and Procedures for the Negotiations on Trade in Services", S/L/93, March 29, 2001, Adopted by the Special Session of the Council for Trade in Services on 28 March 2001.

81 Para. 10. According to the WTO Secretariat approval procedures or licensing and qualification requirements, such as financial soundness or membership in a professional organization, are frequently stipulated as conditions to obtain a license in GATS schedules whereas, legally speaking this is not necessary if the regulations and their application are of a non-discriminatory nature. Disciplines to be developed under GATS Art. VI:4 are meant to ensure that measures relating to qualification requirements and procedures, technical standards and licensing requirements do not constitute unnecessary barriers to trade in services.

82 Art. XIV.

83 See for example WTO-Document S/CSS/W/34, December 22, 2000, Communication of the EC on GATS 2000: Business Services (Other than Professional Services) that illustrates how regulations can be designed 
it is important that the scope of the horizontal commitment is limited to the cross-border delivery of services because many regulation-intensive areas where regulators would not easily grant full commitments (legal representation in court, surgical operations, specific construction work, sewage services) actually cannot be delivered across borders ${ }^{84}$.

\section{Option 2b: Inclusion of a Prudential Carve-Out in Model Schedule 2}

Under this option, in addition to the horizontal commitment, the model schedule would come with a paragraph on regulatory reassurance that is akin to the "prudential carve-out" in financial services, and affirms the right of Members to regulate their service sectors to meet national policy objectives.

Accompanying Note on Domestic Regulation: Notwithstanding these commitments and any other provisions of the Agreement, a Member shall not be prevented from maintaining and introducing new regulations protecting, inter alia, consumers, health, safety, national security, the environment, the financial system, etc. Where such measures do not conform with the provisions of the Agreement, they shall not be used as a means of avoiding the Member's commitments or obligations under the Agreement.

The main reason for this provision is that the GATS is a new, untested Agreement and the implications of its evolving disciplines are not well-established. Members cannot at this stage be sure that their individually preferred balance between national regulatory autonomy and multilateral disciplines will coincide with the eventual legal interpretation. Option 2a describes the GATS as it should be, not necessarily how it is. Consider an example. Say a Member requires cross-border suppliers of insurance services from other jurisdictions to post local bonds. Would this be consistent with national treatment? Yes, one could say, as long as the requirement is reasonably related to the additional prudential concerns associated with cross-border supply. But the question has never been addressed, and it is not certain how precisely a panel will pronounce on this issue.

Therefore, despite the existing right of Members to regulate, the inclusion of the prudential carve-out under this horizontal commitment or at the start of each GATS schedule (see the U.S. initial offer, for example ${ }^{85}$ ) would help to reassure national regulators that the objective is not to question their judgments but to target only blatantly protectionist measures - which is broadly the role of the prudential carve out in financial services. The advantage of this approach is that by accommodating regulatory precaution, it may make it easier for Members

to facilitate cross-border service trade: "The extent to which residency requirements could be replaced by other less trade restrictive measures (i.e. appointment of representative agent, liability insurance, etc.). In our view, residency requirements would be acceptable only for the purpose of consumer protection and, where maintained, because other less trade restrictive measures would not be applicable. In such cases, the period of the residency required as a prior condition to meet the obligation should be reduced to the minimum.".

84 Under these commitments an architect for example would be allowed to prepare and finalize the blueprints for a particular skyscraper construction. However, this commitment would not afford this architect the right to actually implement and supervise the construction work on the spot.

${ }^{85}$ Para. 3 of the US initial offer notes: "Under these proposed new GATS obligations, as under current obligations, the United States will continue to be able to establish, maintain, and fully enforce its domestic laws protecting, inter alia, consumers, health, safety, and the environment, as well as take actions it considers necessary for the protection of its essential security interests." 
to make deeper and wider commitments. The disadvantage is that the value of those commitments will depend on the uncertain interpretation of the scope of the carve-out.

Option 2c: Limiting the Scope of the Horizontal Commitment to Situations Where Businesses Are the Consumers

This option takes on the general ideal of option 2a but limits the scope of the commitment. Specifically, Members would grant full market access and national treatment commitments to all cross-border trade in services that are bought by enterprises. Here the term juridical person is used more widely than the GATS definition to include also branches, representative offices and other legal forms. In other words, only all services transactions where either goods- or services-producing firms are "service importers" are covered.

One issue that immediately arises is that the relationship between this horizontal commitment and the existing limitations in the GATS schedules would have to be clarified. To avoid cumbersome and confusing annotations of sector-specific limitations, the horizontal commitment would have to override existing limitations for business consumers. Sectorspecific commitments would remain relevant, however, when private households are the consumers ${ }^{86}$.

This more limited version of the first option may need to be introduced to overcome the reluctance of regulators to make full mode $1 /$ mode 2 commitments because of consumer protection considerations. The assumption is that private households deserve greater legislative protection than more sophisticated consumers (e.g. firms). While our discussion of the previous section makes it clear that specific commitments do not deprive regulators of the right to regulate, they do expose their actions to some scrutiny and even this may be deemed intrusive.

Under these circumstances, it may be useful to differentiate between the types of "service consumers" and liberate at least the huge and growing cross-border trade in business services from regulatory paternalism. Technically speaking, the GATS defines a service consumer as "any person that receives or uses a service". Whereas both the GATS and the countryspecific GATS schedules differentiate between types of service producers (e.g. to be considered as a "juridical person of another Member" certain conditions must be met ${ }^{87}$ ) the GATS consumer definition makes no such differentiation. However, it should not be difficult to use the notion of juridical person also to define a certain type of consumer that is distinct from the household. ${ }^{88}$ However, since the GATS concept of juridical persons does not include branches or representative offices, this definition would need to be enlarged to any form of business representation. If we take the GATS definition, then the horizontal commitment would apply to "all services in all sectors where juridical persons, branches, representative offices or other businesses are the consumer".

86 This is a departure from option one that only asked for a major reconsideration of existing limitations.

87 (m) "juridical person of another Member" means a juridical person which is either:(i) constituted or otherwise organized under the law of that other Member, and is engaged in substantive business operations in the territory of that Member or any other Member; or (ii) in the case of the supply of a service through commercial presence, owned or controlled by:1. natural persons of that Member.

88 Art. XXVIII (1)"juridical person" means any legal entity duly constituted or otherwise organized under applicable law, whether for profit or otherwise, and whether privately-owned or governmentally-owned, including any corporation, trust, partnership, joint venture, sole proprietorship or association; 
This approach has the obvious advantage of capturing perhaps the most significant element of current cross-border trade in services. The key disadvantage is that trade in a range of services provided to consumers would be excluded. The selective approach not only limits the extent of liberalization, but allows distortions to be created by the possible differential treatment of businesses and consumers. This could lead to socially wasteful expenditure by regulators on monitoring that foreign firms are not illegally supplying to households, or even by households to pass themselves off as businesses to evade restrictions.

\section{CONCLUSION}

The aim of this paper was to identify approaches to securing free cross-border trade in services. The options are intended to form the basis for both domestic and international consultations to determine the precise approach, and the level of liberalizing ambition that is politically sustainable.

The options described here have focused on obtaining market access and national treatment commitments as understood under the GATS. The focus in this paper has been on preempting the introduction of explicit barriers. Complementary steps may be necessary to achieve the broader aim of unfettered cross-border trade in services. Consultations with stakeholders should help identify the nature of the remaining regulatory barriers to trade and how they can be best addressed. Some of these barriers can be addressed under the GATS: possible new rules on regulatory transparency, on domestic regulation and on mutual recognition are relevant to cross-border trade, and could be integrated into the options presented here. Of greatest immediate relevance, several of the protectionist initiatives in the United States involve government procurement contracts. Government procurement is currently excluded from the scope of key GATS rules, and countries remain free to discriminate. Dealing with such restrictions would require a number of countries to reassess their current position on disciplines on government procurement.

Consultations will also need to address how far other complex issues that arise in the context of cross-border services trade (e.g. the issue of applicable jurisdiction, data privacy issues, etc.) can be addressed in the WTO context and where other fora may be more suitable. Much of the deeper integration of regulations that is needed to support the development of crossborder trade in services is already taking place in other contexts, e.g. the OECD is addressing the issue of tax treatment, the WIPO several issues related to the protection of intellectual property rights, and the Council of Europe certain aspects of cyber crime. The challenge is to ensure that the regulatory cooperation in these fora is not exclusionary and leading to regulatory trade diversion but inclusive and encouraging the enhanced participation of developing countries in services trade.

Finally, it must be recognized that the idea of making comprehensive binding commitments is in stark contrast to the GATS tradition of flexibility. The main reason to depart from this position is that there is no obvious gain but an obvious protectionist danger from countries retaining the freedom to impose restrictions on cross-border trade. The ambitious proposal is not particularly radical, since it seeks merely to bind the status quo rather than the relatively painful elimination of existing protection. ${ }^{89}$ Today it may still be feasible to get broad-based agreement on such a proposal when the most dynamic exporters still account for a tiny share

\footnotetext{
${ }^{89}$ Several regional agreements have already incorporated such a commitment (Stephenson, 2002).
} 
of world exports. Tomorrow when the pain of adjustment is more acute, the temptation to use sub-optimal trade policy instruments may be difficult to resist.

In this light, the developing countries which are seeing a rapid increase in services exports, from India and Brazil to Dominica and Mauritius, may support such a proposal if they can overcome their traditional aversion to giving up policy discretion and overcome any domestic opposition to assuring openness of the domestic market to international competition. The United States, with its aggressive support of duty-free electronic commerce as well as the European Union - notwithstanding its defensive interests in the audiovisual sector - may also support such a proposal, both because it secures market access for their exporters and would be a powerful affirmation of the development dimension of the current round of negotiations. It would be highly desirable if the recognition of mutual interest led to a supporting coalition of both industrial and developing countries. Some of the poorer developing countries may, nevertheless, remain apprehensive. In which case, the proposal may need to be developed along the lines of the Information Technology Agreement, i.e. seek participation from a critical mass of countries rather than the entire WTO membership. 


\section{Bibliography}

BECKER, RALF (2001): Central Product Classification - some thoughts on future work, 16th Voorburg Group Meeting on Service Statistics, 2001, http://www.voorburg.scb.se/Voorburg2001-_Classification_UN.doc, UNSD Trade Statistics Branch

CASSAMAJOR, KAREN (2002): Emerging issues - CPC 2007 Revision, 17th Voorburg Group Meeting on Service Statistics, United Nations Statistics Division, September 2002, downloaded from www.insee.fr/en/av_service/colloques/pdf/CLASS6.pdf in April 2003

CAVE, WiLliam (2002): A contribution for the Session on Classifications: Measuring International Trade in Services and New Demands on the Family, 17th Voorburg Group Meeting on Service Statistics, Nantes, September 23-27, 2002

HAUSER, HEINZ and SACHA WUNSCH-VINCENT (2002): The Cross-Border Trade in Electronic Services: The Role of the WTO and Challenges to National Policies, Expert Report for the German Parliament, April 2002, available only in German; downloaded from http://www.wtoresearch.ch

ITC (2000): Offshore Back Office Operations: Supplying Support Services to Global Markets; Geneva: ITC

KIRKEGAARD, JACOB (2003): Stains on the White Collar?, IIE Draft Working Paper, December 2004

MATTOO, AADITYA and LUdGER SCHUKNECHT (2001): A WTO-Framework for the New Economy, Paper presented at the Paderborn Konferenz on "Economic Policy in the New Economy", May 15 - 16, 2001

OECD (2000): Electronic Commerce- Existing GATS Commitments for online Supply of Services; Paris: Trade Directorate (Trade Committee of the OECD); Report Number TD/TC/WP(99)37/Final

STEPHENSON, SHERRY M. (2002), Regional Versus Multilateral Liberalization Of Services, World Trade Review 1 (2), pp. 187-209

United Nations (1991): Provisional Central Product Classification (CPC); Department of Economic and Social Affairs, Statistical Papers, Series M, No. 77, Ver.1.1, E.91.XVII.7, New York: United Nations

United Nations (1998): Central Product Classification (CPC): Version 1.0; Department of Economic and Social Affairs, Statistical Papers, Series M, No. 77, Ver.1.1, E.98.XVII.5, New York: United Nations

United Nations (2002): Central Product Classification (CPC): Version 1.1; Department of Economic and Social Affairs, Statistical Papers, Series M No. 77, Ver.1.1, ESA/STAT/SER.M/77/Ver.1.1, New York: United Nations

WTO (2001): Market Access: Unfinished Business- Post Uruguay Round, Inventory and Issues; Geneva: WTO Economic Research and Analysis Division, Coordinator Marc Bacchetta 
Annex Table 1: Examples of Limitations Scheduled by WTO Members on Cross Border Trade

\begin{tabular}{|c|c|c|}
\hline & Market Access & National Treatment \\
\hline \multicolumn{3}{|c|}{ Horizontal Limitations Mode 1} \\
\hline \multirow[t]{2}{*}{ All Sectors, all modes } & $\underline{\text { Subsidies }}$ & Unbound for subsidies, tax incentives and tax credits \\
\hline & & $\begin{array}{l}\text { 1), 2), 3) At the federal level, with respect to direct taxes: } \\
\text { Differential tax treatment may be provided between national and } \\
\text { foreign trusts. }\end{array}$ \\
\hline Sector & Mode 1 limitations & Mode 1 limitations \\
\hline $\begin{array}{ll}\text { Insurance } & \text { and } \\
\text { Insurance-Related } & \\
\text { ervices } & \end{array}$ & $\begin{array}{l}\text { Promotional activity and intermediation on behalf of a subsidiary not established in XX } \\
\text { are prohibited. } \\
\text { Monopoly rights as indicated in paragraph B. } 1 \text { of the "Understanding": a public } \\
\text { monopoly on fire and natural damage insurance on buildings exists. }\end{array}$ & $\begin{array}{l}\text { Life insurance premium is tax deductible up to a certain amount } \\
\text { for holders of policies issued by local companies }\end{array}$ \\
\hline $\begin{array}{l}\text { Banking and Other } \\
\text { Financial Services }\end{array}$ & Establishment is required for the provision of investment advisory services & \\
\hline Advertising services & $\begin{array}{l}\text { Foreign participation in the production is limited to } 1 / 3 \text { of the footage of advertising films. } \\
\text { Larger participation is conditional on use of local talent and production house. }\end{array}$ & \\
\hline$\underline{\text { Professional services }}$ & $\begin{array}{l}\text { Persons seeking to provide professional services must obtain recognition of their } \\
\text { professional degree, enrol in the relevant college and establish legal domicile in the country }\end{array}$ & \\
\hline Engineering services & Co-operation with local professional organizations required & \\
\hline $\begin{array}{l}\text { Legal advice home } \\
\text { country law and public } \\
\text { international law }\end{array}$ & Unbound for drafting of legal documents & $\begin{array}{l}\text { Unbound for drafting of legal documents. Marketing of legal } \\
\text { advice activities is restricted to lawyers with a local licence to } \\
\text { practise and law firms registered locally. }\end{array}$ \\
\hline $\begin{array}{l}\text { Value-added } \\
\text { Telecommunications }\end{array}$ & $\begin{array}{l}\text { Foreign service suppliers will be permitted to provide services in and between specific } \\
\text { cities. }\end{array}$ & \\
\hline Educational Services & $\begin{array}{l}\text { Condition of nationality. However, third country nationals may obtain authorization from } \\
\text { competent authorities to establish and direct an education institution and to teach }\end{array}$ & $\begin{array}{l}\text { Condition of nationality. However, third country nationals may } \\
\text { obtain authorization from competent authorities to establish and } \\
\text { direct an education institution and to teach }\end{array}$ \\
\hline
\end{tabular}


Annex Table 2: Structure of Existing Commitments on Cross-Border Trade, all Members, on Sectors covered in the Model Schedule under Option 1

\begin{tabular}{|c|c|c|c|c|c|c|c|}
\hline \multirow[t]{2}{*}{ Sector } & \multirow[t]{2}{*}{ Total $^{\mathrm{a}}$} & \multicolumn{3}{|c|}{ Market Access (\%) } & \multicolumn{3}{|c|}{ National Treatment } \\
\hline & & Full & Partial $^{\mathrm{b}}$ & Unbound & Full & Partial $^{\mathrm{b}}$ & Unbound \\
\hline \multicolumn{8}{|l|}{ Business Services } \\
\hline Accounting/auditing/bookkeeping & 70 & 34 & 41 & 24 & 37 & 39 & 24 \\
\hline Taxation services & 47 & 55 & 36 & 9 & 53 & 34 & 13 \\
\hline \multicolumn{8}{|l|}{ Computer and related services } \\
\hline $\begin{array}{l}\text { Consultancy services related to the } \\
\text { installation of computer hardware }\end{array}$ & 66 & 64 & 18 & 18 & 68 & 11 & 21 \\
\hline Software Implementation services & 71 & 61 & 24 & 15 & 65 & 17 & 18 \\
\hline Data processing services & 69 & 59 & 25 & 16 & 62 & 20 & 17 \\
\hline Data Base services & 62 & 61 & 21 & 18 & 66 & 15 & 19 \\
\hline Other & 44 & 52 & 43 & 5 & 57 & 39 & 5 \\
\hline \multicolumn{8}{|l|}{ "Other Business Services" } \\
\hline Management consulting service & 65 & 63 & 23 & 14 & 69 & 18 & 12 \\
\hline Advertising services & 54 & 57 & 31 & 11 & 57 & 24 & 19 \\
\hline Market research / public opinion polling & 52 & 69 & 19 & 12 & 77 & 15 & 8 \\
\hline $\begin{array}{l}\text { Placement and supply services of } \\
\text { Personnel }\end{array}$ & 22 & 50 & 18 & 32 & 59 & 9 & 32 \\
\hline Other "Other business services" $" 90$ & 31 & 16 & 68 & 16 & 16 & 68 & 16 \\
\hline \multicolumn{8}{|l|}{ Communication Services } \\
\hline Online info \& data base retrieval & 70 & 31 & 61 & 7 & 56 & 39 & 6 \\
\hline Educational Services & & & & & & & \\
\hline
\end{tabular}

${ }^{90}$ Includes Telephone answering services, Collection agency services, Duplicating services, Translation and interpretation services, Mailing list compilation and mailing services. 


\begin{tabular}{|l|l|l|l|l|l|l|l|}
\hline Adult education & 34 & 53 & 41 & 6 & 50 & 44 & 6 \\
\hline Other education services & 18 & 28 & 67 & 6 & 32 & 63 & 5 \\
\hline Financial Services & & & & & & \\
\hline $\begin{array}{l}\text { A. All insurance and insurance-related } \\
\text { services, Services auxiliary to insurance }\end{array}$ & 71 & 27 & 46 & 27 & 39 & 31 & 30 \\
\hline $\begin{array}{l}\text { B. Banking and other financial services } \\
\text { 1. Provision and transfer of financial } \\
\text { information, data processing, software }\end{array}$ & 69 & 51 & 7 & 48 & 58 & 30 & 12 \\
\hline $\begin{array}{l}\text { Advisory and other auxiliary financial } \\
\text { services }\end{array}$ & 76 & 32 & 49 & 20 & 39 & 36 & 25 \\
\hline $\begin{array}{l}\text { RECREATIONAL, CULTURAL AND } \\
\text { SPORTING SERVICES, Library and } \\
\text { archive services } 91\end{array}$ & 20 & 33 & 42 & 24 & 40 & 35 \\
\hline
\end{tabular}

Source: Based on data provided by the WTO Secretariat, updates S/C/W/99, March 3, 1999

${ }^{\text {a }}$ Total number of Members with commitments in Mode 1.

${ }^{\mathrm{b}}$ Includes horizontal limitations.

${ }^{91}$ Services of libraries of all kinds. Documentation services, i.e. collection, cataloguing, whether manually or computer-aided, and retrieval services of documents. The services may be provided to the general public or to a special clientele, such as students, scientists, employers, members, etc. Services of archives. Documentation services, i.e. collection, cataloguing, whether manually or computer-aided, conservation and retrieval services of documents, mainly for historical and other scientific purposes. 